\title{
A metabolic study of Buchnera, the intracellular bacterial symbionts of the pea aphid Acyrthosiphon pisum
}

\author{
L. F. Whitehead and A. E. Douglas* \\ Department of Zoology, University of Oxford, South Parks Road, Oxford OX1 3PS, UK
}

(Received 22 September 1992; accepted 15 January 1993)

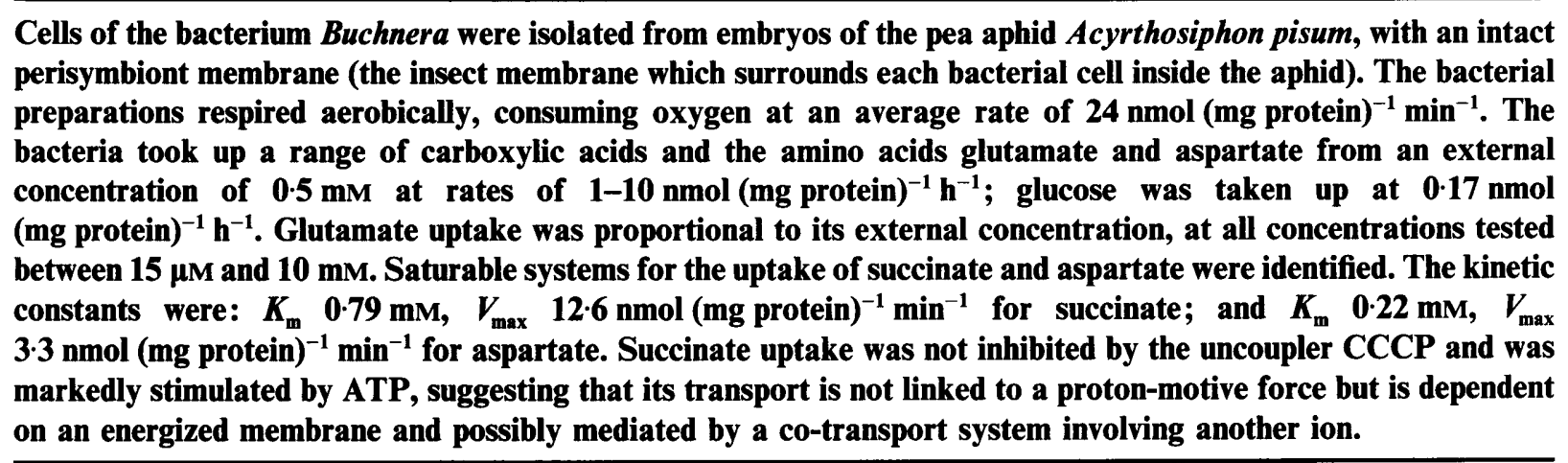

\section{Introduction}

Buchnera is a member of the $\gamma$-Proteobacteria (Munson et al., 1991 a), known only in aphids (phloem-feeding insects of the order Homoptera). The bacteria are restricted to a single type of insect cell, known as the mycetocyte, found within the body cavity (haemocoel) of the aphid. Each bacterium is separated from the surrounding insect cell cytoplasm by an insect membrane, known as the perisymbiont membrane. The bacteria are transmitted maternally via the egg or embryo (Hinde, 1971 ; Brough \& Dixon, 1990), and have no freeliving stage. As yet, it has not been possible to maintain Buchnera in long-term axenic culture, but the bacteria can be isolated from aphids and maintained in a viable condition for several hours (Ishikawa, 1982 $a$; Harrison et al., 1989).

Aphids are dependent on Buchnera for normal growth and fecundity (e.g. Mittler, 1971; Ishikawa \& Yamaji, 1985; Douglas, 1992). It has been shown that aphids derive essential amino acids from Buchnera, supplementing the low essential amino acid content of

*Author for correspondence. Present address: Department of Biology, University of York, York, YO1 5DD, UK. Tel. 090443000.

Abbreviation: CCCP, carbonyl cyanide $m$-chlorophenylhydrazone. their phloem sap diet (Douglas, 1988; Douglas \& Prosser, 1992; Sasaki et al., 1991). Beyond their capacity to synthesize essential amino acids, virtually nothing is known about the metabolic capabilities of Buchnera.

The aims of this study were twofold: to demonstrate unambiguously that isolated preparations of Buchnera are metabolically active; and to identify some carbon sources that Buchnera can utilize. Detailed studies were conducted on compounds which are major substrates for other intracellular micro-organisms or were found to be utilized at high rates by Buchnera.

\section{Methods}

Isolation of Buchnera. The bacteria were isolated from embryos of the pea aphid Acyrthosiphon pisum (Harris) clone Ox-2 (Prosser \& Douglas, 1992). For each experiment 40-50 adult aphids were taken form a parthenogenetic culture of $A$. pisum, maintained on Vicia faba var. The Sutton, at $20^{\circ} \mathrm{C}$ with an $18 \mathrm{~h}$ light: $6 \mathrm{~h}$ dark regime. The embryos were dissected out and homogenized in a glass hand-held tissue grinder with ice-cold Tris/sucrose buffer $(50 \mathrm{~mm}$-Tris $/ \mathrm{HCl} \mathrm{pH}$ 7.5 and $0.25 \mathrm{M}$-sucrose) and $10 \mathrm{~mm}$-dithiothreitol. The homogenate was centrifuged at $3700 \mathrm{~g}$ for $30 \mathrm{~s}$. The pellet was washed once with $0.008 \%$ (v/v) Nonidet-P40 detergent in Tris/sucrose buffer and three times in detergent-free buffer by centrifugation and resuspension. The final pellet was resuspended in incubation medium comprising $0.5 \mathrm{~mm}-\mathrm{MgSO}_{4} .7 \mathrm{H}_{2} \mathrm{O}, 0.3 \mathrm{~mm}-\mathrm{NH}_{4} \mathrm{Cl}, 0.25 \mathrm{M}$-sucrose and $50 \mathrm{~mm}-$ MOPS/NaOH, $\mathrm{pH} 7 \cdot 0$. The protein content of the final bacterial preparation was quantified by the method of Bradford (1976) with bovine serum albumin as a standard. 

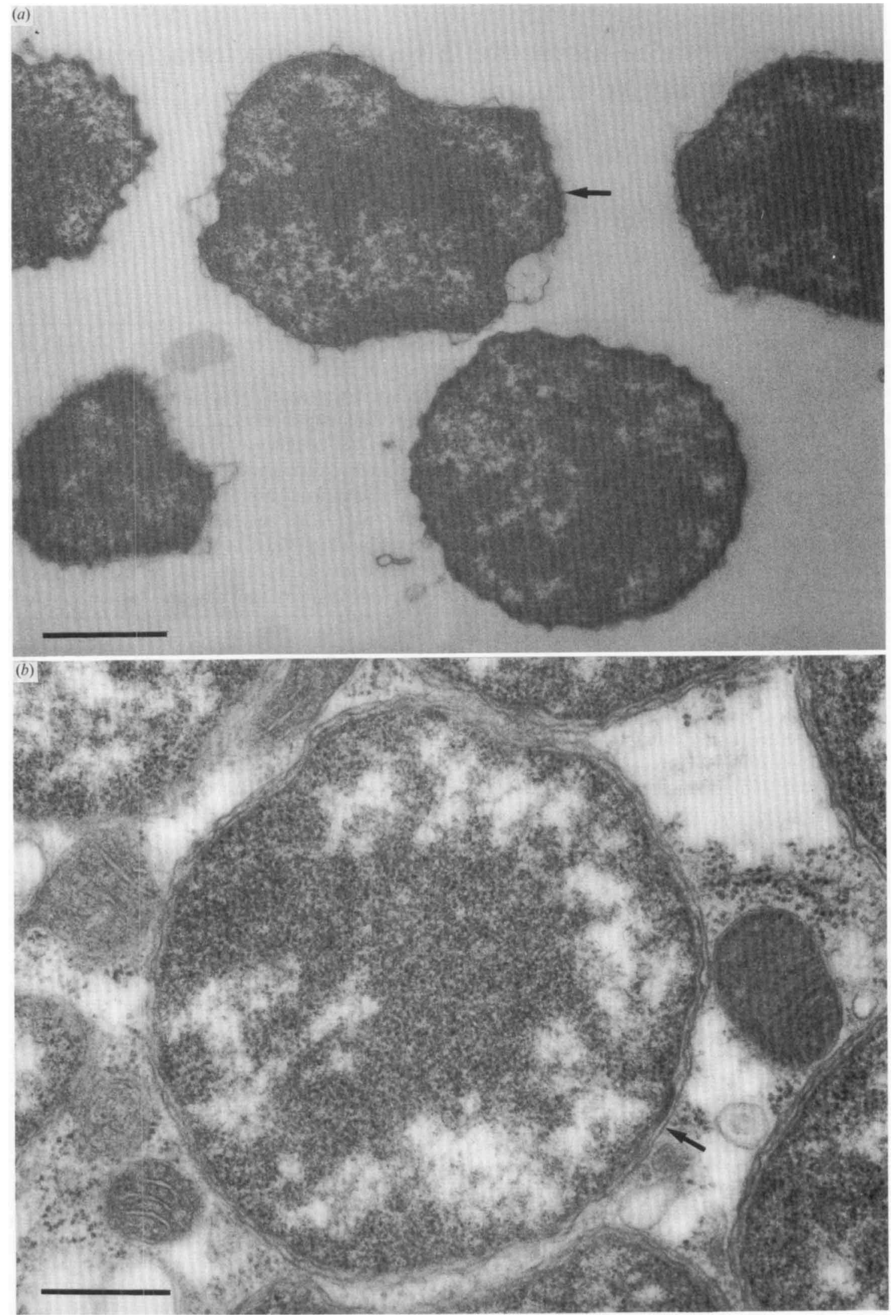

Fig. 1. Transmission electron micrographs of Buchnera within a perisymbiont membrane (arrow): (a) isolated from pea aphid embryos, scale bar $0.7 \mu \mathrm{m} ;(b)$ in the cytoplasm of the aphid mycetocyte, scale bar $0.5 \mu \mathrm{m}$. 
Table 1. Uptake of carbon compounds by preparations of Buchnera over $60 \mathrm{~min}$

\begin{tabular}{lcc}
\hline \hline $\begin{array}{l}\text { Carbon compound } \\
(0.5 \mathrm{mM})\end{array}$ & $\begin{array}{c}\text { Uptake rate } \\
\text { [nmol }(\mathrm{mg} \text { protein })^{-1} \mathrm{~h}^{-1} ; \\
(\mathrm{mean} \pm \mathrm{SE}, n=3)]\end{array}$ & $\begin{array}{c}{ }^{14} \mathrm{C} \text { metabolized to } \mathrm{CO}_{2} \\
\text { (proportion of radiolabel } \\
\text { incorporated by cells) }\end{array}$ \\
\hline Glucose & $0.17 \pm 0.07$ & 0.59 \\
Succinic acid & $1.63 \pm 0.19$ & 0.76 \\
Citric acid & $3.70 \pm 0.14$ & $>0.99$ \\
2-Oxoglutaric acid & $4.70 \pm 0.30$ & 0.91 \\
Glutamic acid & $5.38 \pm 0.04$ & 0.90 \\
Acetic acid & $6.70 \pm 0.53$ & 0.96 \\
Aspartic acid & $10.3 \pm 0.41$ & 0.92 \\
\hline
\end{tabular}

Oxygen consumption by the bacteria. An oxygen electrode (Rank Bros) connected to a continuous linear recorder was used. To calibrate the readings, the relative solubility of oxygen, liberated from a known amount of hydrogen peroxide by catalase, was determined in both distilled water and incubation medium (Dixon \& Kleppe, 1965). Control experiments were performed on bacterial preparations previously incubated at $100^{\circ} \mathrm{C}$ for $5 \mathrm{~min}$. The effect of metabolic inhibitors was examined by adding them to the bacterial preparation $5 \mathrm{~min}$ after recordings were started.

Transport studies. The following radiochemicals were used: [2,3$\left.{ }^{14} \mathrm{C}\right]$ succinate, $\left[1-{ }^{14} \mathrm{C}\right]$ acetate, $\left[\mathrm{U}-{ }^{14} \mathrm{C}\right]$ glucose, $\left[1,5-{ }^{14} \mathrm{C}\right]$ citrate, $[\mathrm{U}-$ $\left.{ }^{14} \mathrm{C}\right]$ aspartate and $2-0 x 0\left[5-{ }^{14} \mathrm{C}\right]$ glutarate from Amersham; and [U${ }^{14} \mathrm{C}$ glutamate from Sigma. Uptake experiments of up to $1 \mathrm{~h}$ duration were conducted in $0.5 \mathrm{ml}$ Eppendorf tubes containing $0.4 \mathrm{ml}$ bacterial preparation $\left(0.5 \mathrm{mg}\right.$ protein $\left.\mathrm{ml}^{-1}\right)$. The reaction was started by adding $5 \mu$ radiolabelled substrate to give a final concentration of $0.5 \mathrm{~mm}$ and $12.5 \mu \mathrm{Ci} \mathrm{ml}^{-1}\left(462.5 \mathrm{kBq} \mathrm{ml}^{-1}\right)$ and samples were shaken at 100 r.p.m. at room temperature. The reaction was terminated by adding ice-cold buffer and centrifuging immediately for $30 \mathrm{~s}$ at $15000 \mathrm{~g}$. The pellet was then washed three times by centrifugation and resuspension and assayed for radioactivity. Zero-time values were obtained and subtracted from all values. For the determination of carbon dioxide evolution, bacterial preparations were incubated as above, but in sealed vials with a wick of filter paper impregnated with $10 \%(\mathrm{w} / \mathrm{v}) \mathrm{KOH}$ inserted into the lid. After $60 \mathrm{~min}$ incubation, $0 \cdot 1 \mathrm{ml}$ glacial acetic acid was injected into the mixture and the vials were shaken at 800 r.p.m. for a further $60 \mathrm{~min}$. The wick was then air-dried and assayed for radioactivity. For short-term uptake studies, $1.2 \mathrm{ml}$ bacterial suspension $\left(1 \mathrm{mg}\right.$ protein $\left.\mathrm{ml}^{-1}\right)$ was incubated in a $10 \mathrm{ml}$ glass beaker at room temperature with constant stirring. The reaction was started by the addition of radiolabelled substrate, to give a final concentration of between 0.015 and $20 \mathrm{mM}$ and $12.5 \mu \mathrm{Ci} \mathrm{m}^{-1}$. At the desired times, $200 \mu \mathrm{l}$ aliquots of the bacteria were removed and transferred onto GF/F filters (Whatman) on a vacuum filter manifold (Amico), and washed with $5 \mathrm{ml}$ incubation medium. The filter was air-dried and assayed for radioactivity. The effect of inhibitors and ATP on the uptake of radiolabelled compounds was examined by adding them to the bacterial suspension $1 \mathrm{~min}$ before the radioactive compound.

Assay of radioactivity. All radiolabelled samples were combined with $4 \mathrm{ml}$ scintillation fluid (Pharmacia Optiphase Hisafe II for aqueous samples, and Optiscint Hisafe for dried filters) and counted in an LKB 1219 Rackbeta scintillation counter with preset ${ }^{14} \mathrm{C}$ windows.

Electron microscopy. Immediately after isolation from aphids, bacterial preparations were fixed for $12 \mathrm{~h}$ in $2.5 \%(\mathrm{w} / \mathrm{v})$ glutaraldehyde in $0.1 \mathrm{M}$-sodium cacodylate buffer $\mathrm{pH} 7.4$ and $8 \%(\mathrm{w} / \mathrm{v})$ sucrose. The fixed cells were suspended in $4 \%(\mathrm{w} / \mathrm{v})$ agarose and post-fixed for $1 \mathrm{~h}$ with $1 \%(\mathrm{w} / \mathrm{v})$ osmium tetroxide in distilled water. Samples were dehydrated through a graded ethanol series $(70-100 \%, v / v)$ and propylene oxide before infiltration in Araldite CY212. Ultrathin sections were stained in a saturated solution of uranyl acetate and $3.5 \%$ $(\mathrm{w} / \mathrm{v})$ lead citrate, and observed in a Philips EM 400 transmission electron microscope.

\section{Results}

\section{Condition of the isolated bacteria}

Most of the bacteria, freshly isolated from pea aphid embryos and examined by phase-contrast microscopy, were coccoid and 2-3 $\mu \mathrm{m}$ in diameter. Between 10 and $20 \%$ of the cells were dumb-bell shaped and these were identified as bacteria isolated while dividing. The bacteria represented $75-80 \%$ of the particles detected in the preparations examined at $\times 800$ magnification; the remainder included lipid droplets and membrane fragments. The dominant structures in preparations examined by transmission electron microscopy were bacterial cells, with insect mitochondria and amorphous membranous structures observed at very low frequency. Every bacterial cell observed was enclosed within a membrane (Fig. 1a). This membrane was interpreted as the perisymbiont membrane which surrounds each cell inside the aphid mycetocyte (Fig. $1 b$ ).

\section{Oxygen consumption}

The bacterial preparations utilized oxygen at a linear rate of $23.7 \pm 1.9 \mathrm{nmol}(\mathrm{mg} \text { protein) })^{-1} \mathrm{~min}^{-1}$ (mean $\pm \mathrm{SE}, n=$ 26) for at least $30 \mathrm{~min}$. Oxygen consumption was reduced by over $80 \%$ by $1 \mathrm{mM}-\mathrm{KCN}$, but it was not affected by $10 \mu \mathrm{M}$-antimycin A, a specific inhibitor of mitochondrial respiration.

\section{Uptake and metabolism of carbon sources}

The preparations of bacteria utilized all of the seven carbon sources tested over $60 \mathrm{~min}$ (Table 1). The substrates with carboxylate groups (i.e. the carboxylic 


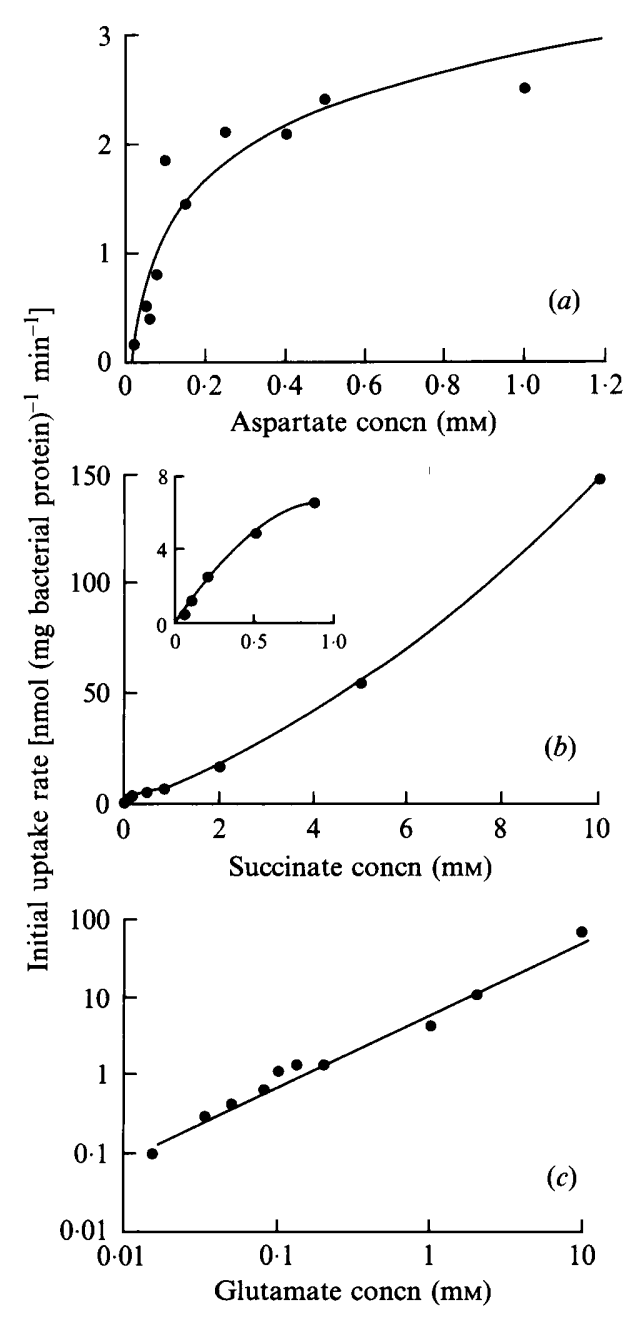

Fig. 2. Effect of concentration on the initial uptake rates of: (a) aspartate: $\quad V_{\max }=3.29 \mathrm{nmol}(\mathrm{mg} \text { bacterial protein })^{-1} \mathrm{~min}^{-1}, \quad K_{\mathrm{m}}=$ $0.22 \mathrm{~mm} ;(b)$ succinate [inset detail of uptake at concentrations $<1 \mathrm{~mm}$ for which $V_{\max }=12.55 \mathrm{nmol}(\mathrm{mg} \text { bacterial protein })^{-1} \mathrm{~min}^{-1}, K_{\mathrm{m}}=$ $0.785 \mathrm{~mm}$; (c) glutamate (NB log scales). Each data point is the mean of two independent experiments.

acids and amino acids glutamate and aspartate) were taken up at a rate of $1-10 \mathrm{nmol}(\mathrm{mg} \text { protein })^{-1} \mathrm{~h}^{-1}$ and between 75 and $>99 \%$ of the incorporated substrate was metabolized to carbon dioxide. Glucose was utilized relatively poorly, with an uptake rate of $0.17 \mathrm{nmol}$ (mg protein) $)^{-1} \mathrm{~h}^{-1}$, and $60 \%$ recovered as carbon dioxide. $\alpha$-Cyanohydroxycinnamic acid $(10 \mu \mathrm{M})$, a specific inhibitor of mitochondrial dicarboxylic acid transport, did not influence the uptake of any carbon source (data not shown).

Further experiments were done to study the transport systems of succinate, aspartate and glutamate. The uptake of all three substrates proceeded linearly for at least $3 \mathrm{~min}$. Uptake plots of $90 \mathrm{~s}$ were used to examine uptake kinetics (Fig. 2). The uptake of aspartate and concentrations of succinate $<1 \mathrm{~mm}$ showed saturation curves consistent with carrier-mediated systems. At higher external concentrations of succinate, uptake was proportional to concentration, indicative of a passive diffusion system. The uptake of glutamate was linear at external concentrations $0.015-10 \mathrm{mM}$, with uptake rates ranging from $0 \cdot 1$ to $60 \mathrm{nmol}(\mathrm{mg} \text { protein })^{-1} \mathrm{~min}^{-1}$.

The uptake of succinate (external concentration $0.87 \mathrm{~mm}$ ) was examined in greater detail. The uncoupler CCCP $(10 \mu \mathrm{M})$ did not depress the initial uptake rate. Cyanide $(1 \mathrm{~mm})$ reduced uptake by $25 \%$, while the addition of $3 \mathrm{~mm}$-ATP resulted in a doubling of the initial uptake rate.

\section{Discussion}

The isolation procedure used here was suitable for metabolic studies of Buchnera because, by both structural and metabolic criteria, the bacterial preparations were not appreciably contaminated with aphid mitochondria or other organelles. The experiments described show that Buchnera does not require the complex cellular environment for basic metabolic functions such as respiration and the uptake of organic compounds. This is consistent with previous demonstrations that isolated bacteria can incorporate inorganic sulphate into reduced organic sulphur compounds including the amino acid methionine (Douglas, 1990), and can synthesize protein and DNA (Ishikawa, 1982b).

There are indications that characteristics of Buchnera in isolation reflect their condition in association with aphids in two respects. Firstly it is very likely that the bacteria respire aerobically in the symbiosis. This is suggested by sustained oxygen consumption of isolated preparations, at rates comparable to the respiration rate of Escherichia coli (Lawford \& Haddock, 1973); and by the particularly rich supply of tracheae (structures which deliver oxygen to insect cells) to mycetocytes (C. N. Brough, personal communication). The second issue concerns the supply of nutrients from the insect mycetocyte cytoplasm to Buchnera. Both in the intact symbiosis and in isolated preparations, each bacterial cell is enclosed within a perisymbiont membrane. The capacity of the Buchnera preparations to take up all seven carbon compounds tested, using each as a respiratory substrate, suggests that Buchnera may not be nutritionally fastidious, and a range of compounds can be transported across the perisymbiont membrane in the pea aphid. Buchnera has probably been in symbiosis for over 200 million years with no free-living phase (Munson et al., 1991 b), and it is very unlikely that these bacteria would have retained the capacity to utilize compounds not available inside the aphid. 
This capacity of Buchnera to utilize such a wide variety of compounds is in sharp contrast to the condition of the only other intracellular symbiont studied in detail, Rhizobium bacteroids from legume root nodules. The principal carbon compounds utilized by the bacteroids are the dicarboxylates malate and succinate [reviewed in McDermott et al. (1989) and Day \& Copeland (1991)]. Bacteroids of rhizobia can barely utilize tri- or monocarboxylates (Ou Yang et al., 1990) or glucose (Salminen \& Streeter, 1987a), all of which are utilized by Buchnera. Also, the legume perisymbiont membrane, but not the aphid perisymbiont membrane, is essentially impermeable to glutamate and aspartate (Herrada et al., 1989).

Succinate transport by the Buchnera preparations was examined in some detail here, because of the importance of dicarboxylates in the nutrition of rhizobial bacteroids. The kinetic constants for the saturable transport system of Buchnera within the perisymbiont membrane are similar to the published values for transport across the perisymbiont membrane of the legume-rhizobium association (Udvardi et al., 1988; Herrada et al., 1989). As with rhizobia (Ou Yang et al., 1990), succinate uptake by Buchnera was stimulated by ATP. However, unlike the rhizobial system, the carrier in the aphid system is probably not linked to proton-motive force, because uptake is unaffected by the uncoupler CCCP. Uptake may be achieved by co-transport with a different ion, e.g. $\mathrm{Na}^{+}$. The slight inhibitory effect of cyanide on succinate uptake suggests that the bacteria are unlikely to provide the major source of energy for the transport system.

Further studies are required to investigate directly the flux of nutrients from the aphid to Buchnera, but one compound of considerable potential interest is glutamate. Buchnera can take up this amino acid from low external concentrations and at high rates; and, furthermore, it is a major intracellular solute, accounting for $30 \mathrm{~mol} \%$ of the total free amino acid pool of Buchnera (L. F. Whitehead, unpublished). Exogenous glutamate is an important carbon source utilized by a variety of intracellular micro-organisms, including the parasites Rickettsia, Chlamydia and Coxiella (Moulder, 1985), and glutamate, derived from dicarboxylates, is the major endogenous respiratory substrate for rhizobium bacteroids (Salminen \& Streeter, 1987b). However, with respect to Buchnera, the potential significance of glutamate extends beyond its role as a respiratory substrate. Glutamate and other non-essential amino acids (possibly including aspartate) may be a source of nitrogen, utilized in the synthesis of essential amino acids, which are then transferred to the aphid. Indirect evidence for this process, which is known as nitrogen upgrading, has already been obtained for the pea aphid symbiosis (Prosser \& Douglas, 1992).
We thank Martin Lomas, who prepared the material for electron microscopy, Professor I. R. Booth and Ms SuPin Koo for advice on uptake studies and Jane Rees for comments on the manuscript. NERC, the Royal Society of London, and a pump-priming grant from the University of Oxford provided financial support.

\section{References}

BradFord, M. M. (1976). A rapid and sensitive method for the quantitation of microgram quanities of protein using the principle of protein-dye binding. Analytical Biochemistry 72, 248-254.

Brough, C. N. \& DiXon, A. F. G. (1990). Ultrastructural features of egg development in oviparae of the vetch aphid, Megoura viciae Buckton. Tissue and Cell 22, 51-63.

DAY, D. A. \& Copeland, L. (1991). Carbon metabolism and compartmentation in nitrogen-fixing legume nodules. Plant Physiology and Biochemistry 29, 185-201.

DiXon, M. \& KLEPPE, K. (1965). D-Amino acid oxidase. 1. Dissociation and recombination of the holoenzyme. Biochimica et Biophysica Acta 96, 357-367.

Douglas, A. E. (1988). Sulphate utilisation in an aphid symbiosis. Insect Biochemistry 18, 599-605.

Douglas, A.E. (1990). Nutritional interactions between Myzus persicae and its symbionts. In Aphid Plant Genotype Interactions, pp. 319-327. Edited by R. K. Campbell \& R. D. Eikenbary. Amsterdam: Elsevier.

Douglas, A. E. (1992). Requirement of a pea aphid (Acyrthosiphon pisum) for their symbiotic bacteria. Entomologia Experientia et Applicata 65, 195-198.

Douglas, A. E. \& Prosser, W. A. (1992). Synthesis of the essential amino acid tryptophan in the pea aphid (Acyrthosiphon pisum) symbiosis. Journal of Insect Physiology 38, 565-568.

Harrison, C. P., Douglas, A. E. \& Dixon, A. F. G. (1989). A rapid method to isolate symbiotic bacteria from aphids. Journal of Invertebrate Pathology 53, 427-428.

Herrada, G., Puppo, A. \& Rigaud, J. (1989). Uptake of metabolites by bacteroid-containing vesicles and by free bacteroids from French bean nodules. Journal of General Microbiology 135, 3165-3171.

HINDE, R. (1971). Maintenance of aphid cells and the intracellular symbiotes of aphids in vitro. Journal of Invertebrate Pathology 17, 333-338.

IsHIKAWA, H. (1982a). Isolation of the intracellular symbionts and partial characterisation of their RNA species of the elder aphid. Acyrthosiphon magnoliae. Comparative Biochemistry and Physiology 72B, 239-247.

ISHIKAWA, H. $(1982 b)$. DNA, RNA and protein synthesis is the isolated symbionts from the pea aphid Acyrthosiphon pisum. Insect Biochemistry 12, 605-613.

IsHIKAWA, H. \& YAMAJI, M. (1985). Symbionin, an aphid endosymbiont-specific protein. I. Production of insects deficient in symbionts. Insect Biochemistry 15, 155-163.

LAWFORD, H. G. \& HADDOCK, B. A. (1973). Respiration-driven proton translocation in Escherichia coli. Biochemical Journal 136, 217-222.

McDermott, T. R., Griffiths, S. M., Vance, C. P. \& Graham, P. H. (1989). Carbon metabolism in Bradyrhizobium japonicium. FEMS Microbiology Reviews 63, 327-340.

MitTLER, T. E. (1971). Some effects on the aphid Myzus persicae of ingesting antibiotics incorporated into artificial diets. Journal of Insect Physiology 17, 1333-1347.

MOULDER, J. W. (1985). Comparative biology of intracellular parasites. Microbiological Reviews 49, 298-328.

Munson, M. A., Baumann, P. \& Kinsey, M. G. (1991a). Buchnera gen. nov. and Buchnera aphidicola sp. nov., a taxon consisting of the mycetocyte-associated, primary endosymbionts of aphids. International Journal of Systematic Bacteriology 41, 566-568.

Munson, M. A., Baumann, P., Clark, M. A., Baumann, L., Moran, N. A., Voegtrin, D. J. \& CAMpbell, B. C. $(1991 b)$. Evidence for the establishment of aphid-eubacterium endosymbiosis in an ancestor of four aphid families. Journal of Bacteriology 173, 6321-6324.

Ou-Yang, L. J., Udvardi, M. K. \& DaY, D. A. (1990). Specificity and 
regulation of the dicarboxylic acid carrier on the peribacteroid membrane of soybean nodules. Planta 182, 437-444.

Prosser, W. A. \& Douglas, A. E. (1992). A test of the hypotheses that nitrogen is upgraded and recycled in an aphid (Acyrthosiphon pisum) symbiosis. Journal of Insect Physiology 38, 93-99.

SALMINEN, S. O. \& STREETER, J. G. (1987a). Uptake and metabolism of carbohydrates by Bradyrhizobium japonicum bacteroids. Plant Physiology 85, 535-540.

SAlMinen, S. O. \& STREeTER, J. G. (1987b). Involvement of glutamate in the respiratory metabolism of Bradyrhizobium japonicum bacteroids. Journal of Bacteriology 169, 495-499.

Sasaki, T., Hayashi, G. \& IshiKawa, H. (1991). Growth and reproduction of the symbiotic and aposymbiotic pea aphids, Acyrthosiphon pisum, maintained on artificial diets. Journal of Insect Physiology 37, 794-756.

Udvardi, M. K., Price, G. D., Greshoff, P. M. \& Day, D. A. (1988). A dicarboxylic acid transporter on the peribacteroid membrane of soybean nodules. FEBS Letters 231, 36-40. 